
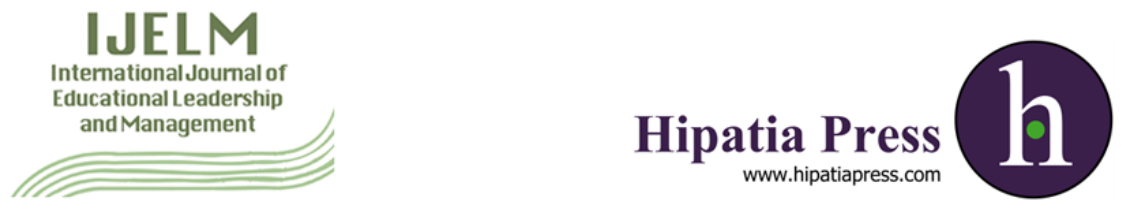

Instructions for authors, subscriptions and further details:

$\underline{\text { http://ijelm.hipatiapress.com }}$

\title{
Measuring the (dis) Satisfaction of the Employees in the Macedonian Companies
}

\author{
Elizabeta Mitreva ${ }^{1}$ \\ Nako Taskov ${ }^{1}$ \\ Zdravko Krivokapic ${ }^{2}$ \\ Jelena Jovanovic ${ }^{2}$ \\ 1) University "Goce Delcev" of Shtip, Macedonia \\ 2) University of Montenegro
}

Date of publication: January $16^{\text {th }}, 2017$

Edition period: January 2018-July 2018

To cite this article: Mitreva, E., Taskov, N., Krivokapi, K. \& Jovanovic, J. (2018) Measuring the (dis) satisfaction of the employees in the Macedonian companies. IJELM, 6(1), 2-17. doi: 10.17853/ijelm.2018.2886

To link this article: http://dx.doi.org/10.17583/ijelm.2018.2886

\section{PLEASE SCROLL DOWN FOR ARTICLE}

The terms and conditions of use are related to the Open Journal System and to Creative Commons Attribution License (CC-BY). 


\section{Measuring the (dis) Satisfaction of the Employees in the Macedonian Companies}

Elizabeta Mitreva

University "Goce Delcev" of

Shtip, Macedonia

Zdravko Krivokapic

University of Montenegro
Nako Taskov

University "Goce Delcev" of Shtip, Macedonia

Jelena Jovanovic

University of Montenegro

\section{Abstract}

The (dis)satisfaction of the employees who create and realize activities is as much important as the satisfaction of the buyers. In this paper, we have presented the results from the research in the Macedonian companies concerning the capacity of the leadership to motivate the employees to do their job efficiently and to preserve their initiative and devotion to the job.

The data received from the research have helped in giving useful information about the business process improvement in defining the measures that need to be taken by the management in order to crate permanent values for the employees, which will satisfy all parties.

The solution has been found in the promotion of the management system through the adoption of the new TQM (Total Quality Management) strategy, then the development of the staff and the teamwork, as well as the advancement of the processes much earlier before purchasing new technology.

Keywords: (dis)satisfaction of the employees; TQM (Total Quality Management) philosophy; quality system; business potential; motivate the employees. 


\section{Midiendo la (in) Satisfacción de los Empleados en Empresas de Macedonia}

Elizabeta Mitreva

University "Goce Delcev" of

Shtip, Macedonia

Zdravko Krivokapic

University of Montenegro
Nako Taskov

University "Goce Delcev" of

Shtip, Macedonia

Jelena Jovanovic

University of Montenegro

\section{Resumen}

La (in)satisfacción de los empleados que crean y realizan actividades es tan importante como la satisfacción de los compradores. En este artículo, hemos presentado los resultados de investigación de compañías en Macedonia sobre la capacidad de liderazgo para motivar a los empleados a hacer su trabajo eficientemente y preserver su iniciativa y dedicación al trabajo.

Los datos de la investigación han ayudado a dar información útil sobre el proceso de mejora del negocio definiendo medidas que necesitan llevarse a cabo desde gestión para crear valores permanentes para los empleados, que satisfarán todas las partes.

La solución se ha encontrado en la promoción del sistema de gestión a través de la adopción de la nueva estrategia TQM (Total Quality Management), después el desarrollo del personal y del equipo de trabajo, así como el avance de los procesos mucho antes de la compra de nueva tecnología.

Palabras clave: (in)satisfacción de los empleados; filosofía TQM (Total Quality Management); sistema de calidad; potencial de negocio; motivación de empleados. 



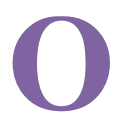

ne of the criteria for receiving a European Quality Award (EQA) is the way the company conducts the employees. A good quality of the products/services can be achieved solely with satisfied employees ( $\mathrm{Li}$ \& Yang, 2003; Wilkes \& Dale, 1998).

The company cannot create competitive advantages in the severe competence in the home or the international market without building permanent values for the employees based on trust and respect. The development and the maintenance of the competitive value of a company on the market is in direct correlation to the resources and capacities, especially the employees' business potential that consists of their knowledge, skills, inventiveness, leadership abilities and other elements necessary for dealing with the changes and also the production of measurable results (Kaplan \& Norton, 1995; Kaplan \& Norton, 2001; McManus, 2006; Malina \& Selto, 2001).

Herein, according to Chepujnoska and Bjen (2000), derives the role of the top managers of the companies responsible for providing quality of the products/services by making all of the employees satisfied. The top management of the companies has to found a way to motivate the employees to devotedly do their job and to preserve their imitativeness (Malina \& Selto, 2001).

\section{Literature review}

The companies are aware of the role and the importance of the motivation and the satisfaction of the employees over the efficiency of the work. In the era of knowledge, more and more time is devoted to measuring the (dis)satisfaction of the employees and discovering the degree of motivation. The management of the employees is an important aspect of the TQM (Total Quality Management) philosophy (Ciampa, 2005; Taskov \& Mitreva, 2015; Ritchie \& Dale, 2000; Sharp, et al., 2000).

The reasons behind the employees' satisfaction for Kondo (1995) are the following: the work conditions, the salary and the other advantages. Also very important are the relations among the employees, the changes in the management, the protection policy, the controlled sick leaves, the absence from work, solving incidents or complaints, the trend of accepting new staff, 
using privileges or using the capacities owned by the company (for recreation, strikes etc.).

The satisfied employees strived toward an improvement, or i.e. an effort to raise the quality of the products/services on a higher level. The key factor is the material and the instrumental equipment of the work place, especially in the informatics and the communicational relation that are a factor in the effectiveness and the efficiency of the business processes (Babatunde \& Pheng, 2015). The employees that are not motivated for work have a very low business success. The unmotivated employees are not interested in the quality of the products and services; they do not identify with the organization's values, are not connected to the organization or their problems, the development or the success and are often ready to leave that organization (Balbaster Benavent et al., 2005, Chen \&Yang, 2006; Kondo, 1995; Francis \& Young, 2012; Parker, 2003; Sethi, 2000).

The communication between the management and the employees as well as the permanent study can contribute greatly to the personal development of the individual, and to improve the organization where the employee works.

Conti (2007) suggests that the quality of the products/services depends on the design of the process and the available resources with the aim obtain results for all stakeholders, but it chiefly depends on the (dis)satisfied employees.

The system for quality provision as one of the functions of the organizations enables the survival on the market, but at the same time, it seeks the participation of all the employees so that the wanted quality of the products/services is achieved. The danger can appear when in the process of system implementation or when every business process does not include the business philosophy of the company. The decision to develop the system for quality provision can go hand in hand with the growth of the company and he mature conception of the TQM (Total Quality Management). Herein, it can be concluded that it is impossible to adopt the TQM philosophy without a formal system for providing quality (Chepujnoska \& Bjen, 2000; Taskov \& Mitreva, 2015; Molla, 2014).

However, the developed countries are not satisfied with the success of the leading systems on the market, because their predictions for the future are not very good. The changes of the environment in the organizations themselves on one hand, and the growth and the development of the organization on the other hand can be complemented factors if the 
organization establishes a dynamic process of the internal changes. These changes should give a response to the outside changes and to obtain a market competitiveness of the organization. This process of internal changes is consisted in the new TQM strategy (Mitreva, 2011; Francis \& Young, 2012).

Kaplan and Norton (2001) believe that the human potential together with the organizational culture of the company are much more valuable than the visible capital. In that way people represent an important source for a maintainable competitive advantage.

The knowledge that the organization has is mostly in the heads of the employees (Sethi, 2000). Also we shouldn't forget the fact that shows that $70 \%$ of the completely adopted knowledge is gained through the non-formal study environment (Mitreva, 2011; Samuelsson, \& Nilsson, 2002).

The corporative culture exists as a fruitful field that creates conditions for permanent studying through a positive climate (Parker, 2003).

According to Sethi (2000), the key rule is to stimulate those forms of employees' behavior that contribute to the realization of the business strategy and the realization of the organizational aims. This means that the motivation has to be in a certain could to guide the people to participate in the life of the organization, to accept and to divide the same paradigm (Chen, 2009; Garg, 2014).

\section{Methods in the research and analyses of the results}

The subject of interest in this paper is an analysis of the Macedonian companies in relation to the care and the devotion to the management of the employees and measuring their (dis)satisfaction with the work (Eskildsen et al., 2001; Aziri, 2011; Van Saane et al., 2003). The aim of the research is to note the fact that as perfect as the organization is, its activities can be counterproductive if all the employees are weakly motivated. In accordance to the defined aims of the empirical research, the list of the researched companies that consists of 3109 Macedonian companies, which was made by the Economic Chamber of RM. The research was done through a questionnaire and with a detailed study of the companies by the researched team. The flow of the research itself was realized with the participation of only 363 companies which is $11,6 \%$ of the created basis, and it is a usual number for this kind of a research (Bohdanowicz et al., 2005; Medina-Munoz \& GarciaFalcon 2000). 
The research in the Macedonian companies was done through the criteria for obtaining the European Quality Award: leadership, politics and strategy, managing employees, resources and processes, the satisfaction of the buyers/users, the satisfaction of the employees, the influence on the association, the business results and the contributions in innovation. These are the criteria which were used for measuring the position of the Macedonian companies in relation to the European Quality Award (Madan, 2010; Sarria Ansoleaga, 2007; Uygur \& Sümerli, 2013).

In this paper, because of the magnitude of the research, we have presented only the results about managing the employees and building trust and respect, which represents basis for a continuous development of the quality system and the readiness to accept the TQM philosophy (Carlos Bou-Llusar, 2005).

The structure of the questioned companies - participants in the research according to the economic branch to which they belong (National classification of jobs Res.2 - 'Official Gazette of RM', no.147/08) and changes and addition of the National classification of jobs applied since 01 January 2013) is given on Figure 1

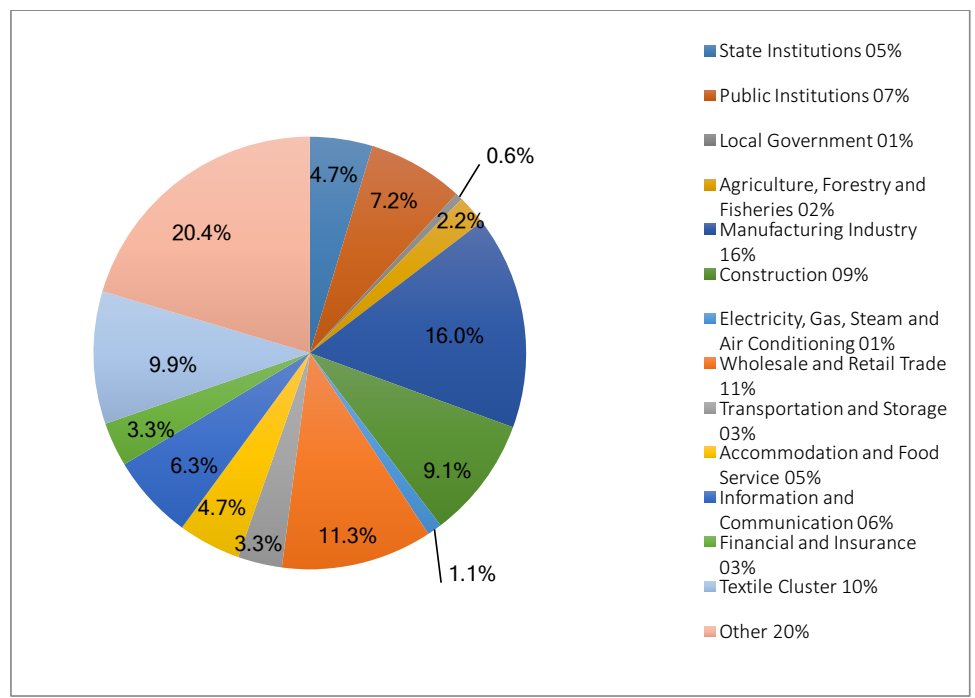

Fig.1. The companies' participation in the research given in percentages according to the economic branches 


\section{Measuring the (dis)satisfaction of the employees in the Macedonian companies}

The managing of the employees is an important aspect of the quality system (Fields, 2002; Prodanovska \& Mitreva, 2013). One of the criteria for receiving the European Quality Award is the way the company measures the (dis)satisfaction of the employees with the management and the business policy. The companies are aware of the role and the importance of the employees' motivation and satisfaction for the work. The management pays more and more attention on measuring the employees' satisfaction and discovering the degree of their motivation (Mitreva \& Filiposki 2012a).

The standardization of the work and the introduction of the quality system do not guarantee the success of the organization (Mitreva \& Filiposki 2012b). The top management of the companies has to find a way to motivate the employees to do their job efficiently and to face their imitativeness and devotion to the job. The satisfied collaborators strive for improvement or i.e. an effort to raise the quality of the products/services on a higher level. The key factor is the material and instrumental equipment of the workplace, especially the informational and communicational connections which are important factors for the effectiveness and the efficiency of the business processes (Mitreva et al., 2016a).

The Macedonian practice shows that the quality in the process of creation of those relations is part of the organization's policy, and it is chiefly concerned with the formal and bureaucratic provision of quality for those relations.

On the question, if the company measures the (dis)satisfaction of the employees in any way or if it discovers the degree of motivation gave the following results:

- $44,6 \%$ of the participants have responded that the managers lead each conversation with each employee individually and in that way they measure the employees' satisfaction with the job;

- $23,1 \%$ of them have responded that the satisfaction of the employees with the work is measured by the managers through conducting a group conversation with workers that do the same job;

- $\quad 20,7 \%$, do not assess the employees' satisfaction with their work; 
- $11,6 \%$, assess the employees' satisfaction with an anonymous questionnaire that is the most real method.

The biggest concern about how much are the employees' satisfied with their work in the company is show by those in the retail and the wholesale trade, as well as the organizations that are concerned with the financial work and the insurance. The least concerned about the employees are the companies in transport and storage business, buildings for accommodation and services for food.

The most objective way of measuring the (dis)satisfaction of the employees is through an anonymous questionnaire, because in that way we can note the real condition, while conducting separate conversation with the employees or a group conversation causes certain fear and uncertainty for the employees and it is difficult for them to state their opinion. The workers are afraid of the direct conversations with their superiors, because they believe they can lose their workplace.

Having in mind the current conditions in Macedonia, the top management has to operate in the direction of higher respect and motivation of the workers and their distribution in suitable workplaces that are compatible with their specialty. We have to emphasize the need for continuous development of their knowledge in order to increase their satisfaction.

On the question if there is loyalty of the employees toward the company, we received the following results:

- It is interesting that $5,5 \%$ of the companies have stated that there is no loyalty by the employees. This condition results from the lack of effort by the managers to create clear, consistent and honourable relations with the employees as well as a professional relation to the work, which is basis for establishing trust in the business processes. This shows us that the companies question the management and the survival of the organization;

- $94,5 \%$ of them have stated that there is loyalty by the employees toward the company, but it needs to be mentioned that these answers were received by the managers.

Having in mind the fact that only $11,6 \%$ of the researched companies assess the employees' satisfaction with an anonymous questionnaire (the most realistic method) and it is reasonable to be suspicious about the data. 


\section{How does the company care about the employees?}

Carefully revise your text to avoid typos. In order to find the way in which the company cares about the employees we need to ask the following question: In which way does the company realize an effective dialogue with the employees or i.e. in which way is the communication conducted in the company:

- $43 \%$ of the companies have stated that there are different developed communication in all directions, including the diagonal;

- $39,4 \%$ of them have stated that there is vertical and horizontal communication in their companies which helps the managers to evaluate the efficiency of their communication and it enables them to detect the organization's problem;

- $14,3 \%$ of them have stated that there is formal communication and only from the top then downwards which shows the ,hard" behavior of the top management, without the necessity of an effective upward communication or hearing the employees' suggestions and wishes for developing the business processes;

- $3,3 \%$ of the companies have stated that the vertical communication is good, but the horizontal communication in their companies has been cut.

In the companies with an established quality system, there are procedures and guidelines for the realization of the business processes. The descriptions of the workplaces and the work tasks are documents that the top management uses to communicate with the employees. The organizational culture as a system of values and beliefs is transmitted to the employees through the downward communication, while the upward communication is a tool that the top management uses in order to hear the voice of the people or i.e. to receive source, elaborated and synthesized data for the work. On the other hand, the horizontal communication enables an exchange of the information among the employees on the same level in the hierarchy and it is essential for the coordination of the business processes.

In order to note the way in which the top managements has established the quality system through procedures and guidelines for the realization of the business processes, we ask the following question: In which way do the managers communicate with the employees: 
- $52,6 \%$ of the companies have stated that the managers give clear and documented obligations and orders, which are followed by clear instructions;

- $22,9 \%$ have stated that the managers give clear orders, but from case to case;

- $19,3 \%$ have stated that the process of giving orders is not defined at all;

- $5,2 \%$ of the companies have stated that they have strict rules for giving orders, but they aren't being followed.

The received data shows the differences among different companies according to the way in which they collaborate with their employees, as well as the way they collaborate in the organization itself. The formal communications from the top downwards are most present in construction, agriculture, silviculture and fishery and the service branches.

There is a great difference in conducting the companies with a private and state capital in relation to the internal and the external communication. In many private companies (even $60 \%$ of the questioned), there is better communication, more efficient solving of the problems and surpassing of the conflicts.

In the state companies there are opposite notions: the communication is underdeveloped, the employees are not keen on collaboration, and the conflicts are hard to surpass. All of these causes a partial loyalty by the employees toward the company as a result of the lack of effort by the managers to create clear, concise and honourable relations with the employees as well as a professional relation to the work, which is the basis for establishing business relations.

\section{Conclusion}

It can be concluded, from the questionnaire and the personal notions, that the Macedonian managers built formal relations to the employees without the wish to essentially build those relations, to define the obligations and the responsibilities and to improve the quality. The formal creation of relations does not bring the wanted results, because we cannot expect good quality product or service from the bad quality of those relations.

The solution of the problems is applied in the TQM strategy through a decrease of bureaucracy and formalism everywhere that is possible. In order 
to achieve a maintainable development, the Macedonian companies need to stop the old habits and proactively direct themselves toward developing the partnership relations with the employees, giving technical support for training to improve the processes, the quality of the products and productivity. The application of the system for total management of quality requires the change of "the consciousness about quality" that has to be mostly present in the top management and then among the employees (Mitreva et al., 2016a; 2016b).

In order to accept the new TQM philosophy, it is necessary to change the existing culture, which is a process that is sometimes conducted successfully (although much energy and time is needed), and sometimes it is only the adjustment of the existing culture that is achieved (James, 1996; Taskov \& Mitreva, 2015). The employees need to learn that the changes are normal, and the top management needs to give them the possibility to adjust to those changes and be their creators. This means that the employees need to be motivated and included in the projection and the implementation of the TQM strategy as well as in the creation of new products and processes (Prodanovska \& Mitreva, 2013). Only those organizations and their employees that possess knowledge and an analysis and diagnosis of the weak places can contribute to a continuous improvement of the quality of the business processes. If you practice a regular control on all the employees, then it is easier to accept the TQM philosophy and the employees adapt more easily to the changes. If an opportunity for more creative working, giving professional contribution and respecting the personal opinions and views is being created, then appears the feeling of usefulness in the process of conducting the company and the feeling of common spirit to succeed (Williams et al., 2006).

If we integrate the knowledge of all the employees, then we can achieve a complete power over the quality in all the business processes of the company with the lowest work costs.

If the rights, the rules and the responsibility are well defined for each individual, then the long-term aims for the work of the companies and the satisfaction of the buyers/users' requests have an absolute advantage in relation to the short-term maximization of the profit.

The top management in each company needs to motivate the employees, and with that to create readiness of the employees to show a high level of an effort in achieving the organizational aims, which are conditioned by the 
ability to fulfil the individual needs. Every input effort needs to be directed toward the organizational aims, but also the needs of the individuals have to be compatible with the aims of the organization.

Herein, one of the essential tasks of the top management is to build a motivational system during the introduction of the integral conduct with the quality. This means: total motivational factors, also motivational measures and strategies that will be strategically and systematically incorporated in the work activities and the organizational activities aiming to motivate the employees (Taskov \& Mitreva, 2015).

In order to have a quality motivational system, we need to obtain four types of behavior (Gómez Gómez et al., 2011; García-Bernal et al., 2004):

- To attract and keep the best people;

- To provide quality realization of the undertaken tasks;

- To motivate the creativity and the innovativeness by finding quick and quality solutions to the problems;

- To provide an identification of the employees to the organization and hiring them in the organization's continuous development.

\section{Acknowledgments}

This study is a part of the research project "Developing a model for performance improvement of business processes by an application of benchmarking strategy based upon examples of innovation", (Ref. No. 17-1395/1).

\section{References}

Aziri, B. (2011). Job Satisfaction: A Literature Review. Management Research \& Practice, 3(4), 77-86. [ Google Scholar]

Babatunde, Y., \& Pheng, L. S. (2015). Cross-cultural management and quality performance: Chinese construction firms in Nigeria. Singapore, Springer. DOI 10.1007/978-981-287-362-0

Balbaster Benavent, F., Cruz Ros, S., \& Moreno-Luzon, M. (2005). A model of quality management self-assessment: an exploratory research. International Journal of Quality \& Reliability Management, 22(5), 432-451. DOI https://doi.org/10.1108/02656710510598366

Bohdanowicz, P., Simanic, B., \& Martinac, I. (2005). Environmental training 
and measures at Scandic Hotels, Sweden. Tourism Review International, $\quad 9(1), \quad 7-19$. https://doi.org/10.3727/154427205774791744

Carlos Bou-Llusar, J., Escrig-Tena, A. B., Roca-Puig, V., \& Beltrán-Martín, I. (2005). To what extent do enablers explain results in the EFQM excellence model? An empirical study. International Journal of Quality \& Reliability Management, 22(4), 337-353. DOI https://doi.org/10.1108/02656710510591192

Chepujnoska, V., \& Bjen, D. (2000). Using TQM to achieve more Efficient Work: the Macedonian Experience. In International Conference on Economic Aspects of Quality Management, Athens. September, 25.

Ciampa, D. (2005). Almost ready: how leaders move up. Harvard business review, 83(1), 46-53. 116] (PMID:15697112)

Chen, S. H., Yang, C. C., Shiau, J. Y., \& Wang, H. H. (2006). The development of an employee satisfaction model for higher education. the TQM Magazine, 18(5), 484-500. https://doi.org/10.1108/09544780610685467

Conti, T. A. (2007). A history and review of the European Quality Award Model. The TQM magazine, 19(2), 112-128. DOI https://doi.org/10.1108/09544780710729962

Eskildsen, J. K., Kristensen, K., \& Jørn Juhl, H. (2001). The criterion weights of the EFQM excellence model. International Journal of Quality \& Reliability Management, 18(8), 783-795. DOI: https://doi.org/10.1108/EUM0000000006033

Francis, D., \& Young, D. (2012). Mehr erfolg im team: ein trainingsprogramm mit 46 ubungen zur verbesserung der leistungsfähigkeit in arbeitsgruppen Windmühle. Germany.

Fields, D. L. (2002). Taking the measure of work: A guide to validated scales for organizational research and diagnosis. London: Sage.

García-Bernal, J., Gargallo-Castel, A., Pastor-Agustín, G., \& RamírezAlesón, M. (2004). Total quality management in firms: Evidence from Spain. The Quality Management Journal, 11(3), 20. [Google Scholar]

Gómez Gómez, J., Martínez Costa, M., \& Martínez Lorente, Á. R. (2011). A critical evaluation of the EFQM model. International Journal of Quality \& Reliability Management, 28(5), 484-502. https://doi.org/10.1108/02656711111132544

Garg, P. (2014). Impact of employee engagement on it sector. International 
Journal of Management Research and Reviews, 4(1), 62. [Google Scholar]

James, P. T. (1996). Total quality management: An introductory text. New Jersey: Prentice Hall.

Kaplan, R. S., \& Norton, D. P. (1995). Putting the balanced scorecard to work. Performance measurement, management, and appraisal sourcebook, 66, 17511. [Google Scholar]

Kaplan, R. S., \& Norton, D. P. (2001). The strategy-focused organization: How balanced scorecard companies thrive in the new business environment. Boston, Massachusetts: Harvard Business Press.

Kondo, Y. (1995). Companywide quality control: its background and development. 3A Corporation.

Li, M., \& Yang, J. B. (2003). A decision model for self-assessment of business process based on the EFQM excellence model. International Journal of Quality \& Reliability Management, 20(2), 164-188. DOI: https://doi.org/10.1108/02656710310456608

Malina, M. A., \& Selto, F. H. (2001). Communicating and controlling strategy: an empirical study of the effectiveness of the balanced scorecard. Journal of management accounting research, 13(1), 47-90. DOI: https://doi.org/10.2308/jmar.2001.13.1.47

Mitreva, E. (2011). Model-integral methodology for successful designing and implementing of TQM system in Macedonian companies. International Journal for Quality Research, 5(4), 255-260. UDC: 005.6:65.012.32

Medina-Muñoz, D., \& García-Falcón, J. M. (2000). Successful relationships between hotels and agencies. Annals of Tourism Research, 27(3), 737-762. DOI: https://doi.org/10.1016/S0160-7383(99)00104-8

Molla, M. I. H. (2015). Ensuring job satisfaction for managing people at work. Global Disclosure of Economics and Business, 4(2), 155-166. [Google Scholar]

Mitreva, E., \& Filiposki, O. (2012a). Proposal methodology of the subsysteminternal standardization as part of TQM system. International Journal for Quality Research, 6(3), 251-258. [Google Scholar]

Mitreva, E., Nikolov, E., \& Nikolova, B. (2016a). Application of Total Quality Management (TQM) in the Macedonian Railways Transport in the Republic of Macedonia. Calitatea, 17(151), 55. [Google Scholar] 
Mitreva, E., \& Filiposki, O. (2012b). Proposed methodology for implementing quality methods and techniques in Macedonian companies. Journal of Engineering \& Processing Management, 4(1), 33-46. DOI: 10.7251/JEPM1204033M

Mitreva, E., Nikolov, E., Nikolova, B., Taskov, N., \& Dimitrov, N. (2016b). Methodology for Optimizations of Business Processes in Macedonian Railways-Transport in the Republic of Macedonia. Mediterranean Journal of Social Sciences, $7(3$ S1), 394. DOI: 10.5901/mjss.2016.v7n3s1p394

Madan, P. (2010). An award journey for business excellence: the case study of a public sector unit. Total Quality Management, 21(12), 13431364. DOI: https://doi.org/10.1080/14783363.2010.530774

Taskov, N., \& Mitreva, E. (2015). The motivation and the efficient communication both are the essential pillar within the building of the TQM (total quality management) system within the Macedonian Higher Education Institutions. Procedia-Social and Behavioral Sciences, 180, 227-234. DOI: 10.1016/j.sbspro.2015.02.109

Parker, G. M. (2003). Cross-functional teams: Working with allies, enemies, and other strangers. San Francisco: John Wiley \& Sons.

Prodanovska, V., \& Mitreva, E. (2013). Incorporation, authorization and encouragement of the employees in order to improve the quality of the educational process, Cambridge Scholars Publishing, Newcastle upon Tyne, UK.

Ritchie, L., \& Dale, B. G. (2000). Self-assessment using the business excellence model: a study of practice and process. International Journal of Production Economics, 66(3), 241-254. DOI: https://doi.org/10.1016/S0925-5273(99)00130-9

Sethi, R. (2000). Superordinate identity in cross-functional product development teams: Its antecedents and effect on new product performance. Journal of the Academy of Marketing Science, 28(3), 330-344. DOI: https://doi.org/10.1177/0092070300283003

Samuelsson, P., \& Nilsson, L. E. (2002). Self-assessment practices in large organisations: Experiences from using the EFQM excellence model. International Journal of Quality \& Reliability Management, 19(1), 10-23. DOI: https://doi.org/10.1108/02656710210413426

Sarria Ansoleaga, R. (2007). EFQM excellence model implementation in Metro Bilbao. Dyna, 82(4), 6-8. [Google Scholar]

Uygur, A., \& Sümerli, S. (2013). EFQM excellence model. International 
Review of Management and Business Research, 2(4), 980. [Google Scholar]

Van Saane, N., Sluiter, J. K., Verbeek, J. H. A. M., \& Frings-Dresen, M. H. W. (2003). Reliability and validity of instruments measuring job satisfaction - a systematic review. Occupational medicine, 53(3), 191-200. DOI: https://doi.org/10.1093/occmed/kqg038

Wilkes, N., \& Dale, B. G. (1998). Attitudes to self-assessment and quality awards: A study in small and medium-sized companies. Total Quality Management, $9(8)$,

731-739.

DOI: https://doi.org/10.1080/0954412988208

Williams, R., Bertsch, B., Van der Wiele, A., Van Iwaarden, J., \& Dale, B. (2006). Self-assessment against business excellence models: a critiqueand perspective. Total Quality Management and Business Excellence, 17(10), $1287-1300$.

DOI: https://doi.org/10.1080/14783360600753737

Elizabeta Mitreva is professor at the University of Goce Delcev in Stip, Republic of Macedonia. She is specialized for meaning and the perspectives of the designing and implementation on TQM (Total Quality Management) system from the viewpoint of researching of its participation within the domestic companies and creating a model methodology for improved performance, efficiency and effectiveness with the Macedonian companies through changing of the corporative culture and total utilizing of potentials.

Address: Krste Misirkov“ No.10-A P.O. Box 201, Stip 2000, Macedonia Email: elizabeta.mitreva@ugd.edu.mk

Nako Taskov is is professor at the University of Goce Delcev in Stip, Republic of Macedonia.

Address: Krste Misirkov“ No.10-A P.O. Box 201, Stip 2000, Macedonia

Email: nako.taskov@ugd.edu.mk

Zdravko Krivokapic is professor at the Faculty of Mechanical Engineering Podgorica, University of Montenegro

Address: Faculty of Mechanical Engineering Podgorica, University of Montenegro

Email: zdravkok@ac.me

Jelena Jovanovic is professor at the Faculty of Mechanical Engineering Podgorica, University of Montenegro

Address: Faculty of Mechanical Engineering Podgorica, University of Montenegro

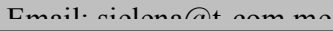

